\title{
Broken Society, Anti-social contracts, Failing State ? Rethinking Youth Marginality
}

\author{
Peter Squires $\quad \& \quad$ Carlie Goldsmith \\ Professor of Criminology \& Public Policy; Executive Director, North Social Research \& Training.
}

Pre-publication edit of chapter: for definitive version please refer to the published chapter in S.Blackman \& R. Rogers (ed.) Youth Marginality in Britain: Contemporary Studies of Austerity, (Policy Press, Bristol, 2017)

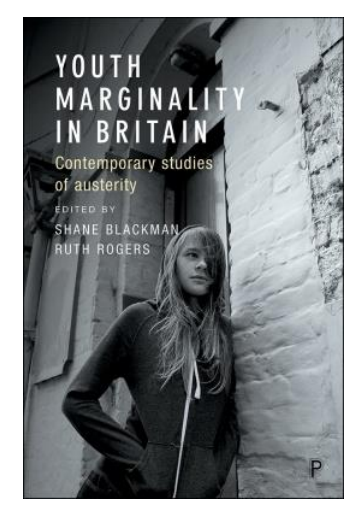

INTRODUCTION:

Central to our analysis here is a critical reinterpretation of the pervasive conservative 'common sense' regarding inequality and the social exclusion of substantial sections of contemporary working class youth, and concerning crime and disorder. We begin by engaging with three core components structuring and sustaining this social exclusion of youth: the ideology of the 'broken society'; the variety of anti-social 'contracts' and compliance processes to which many marginalised young people have become subject; and the failing state with which they frequently have to deal. We question each of these components of neo-liberal political ideology and especially the way in which they combine to blame the victims of failing neo-liberal governance for a wide range of social problems, utilising their ascribed culpability to justify tougher compliance measures, sanctions, disciplines and punishments. In contrast we argue that it has been the pursuit of neo-liberal free market policies which have exacerbated contemporary inequalities while fostering a powerful ideology of individualism that has generated the precarious situation of marginalised youth as collateral harm. Our argument presents the claim that, as neo-liberalism fails youth, so it too fails as governance. Yet states do not fail, overnight, or even all at once; a failing state can still be strong and dangerous. But the more that states fail to achieve certain minima of human rights and social provisions, the more they slip down the 'quality of life' league tables, then the less they reflect a collective public interest, the less legitimacy they possess and the more broken the social and cultural contract upon which they depend.

\section{The Broken Society?}

The 'broken society' discourse played a key role in the re-working of Conservative Party strategies for welfare reform, family policy, youth 'disaffection' and crime control (Cameron, 2008a; Driver, 2009). According to Mooney (2009), the notion of a 'broken society', echoing the moralistic tone of the 'broken windows' analysis on crime and community decline (Wilson and Kelling, 1982) which came to dominate crime prevention thinking in the final decades of the 20th century, initially appeared to suggest a different way of understanding of social problems in contemporary Britain. However, as Mooney concluded, this view was 'largely underpinned by an individualistic and moralistic view of poor people as a distinctive group apart from 'mainstream' society... and a thinly disguised culture of poverty argument that people experiencing poverty are lacking in the capacity 
to escape poverty, gripped by fatalism and apathy' (Mooney, 2009: 447). In turn, such attitudes were said to fuel crime, anti-social behaviour and youthful violence and disorder. In its totality, the 'broken society' argument was not a million miles from the 'underclass ' discourse which had worked its pernicious effects in the 1990s (Murray, 1990) even though this idea, imported from the USA, had never been supported by reliable evidence in the UK context (Smith, 1992; Morris and Irwin, 1992; MacDonald, 1997).

Characteristic of neo-liberal politics, the emerging 'broken society' commentary blamed individuals for social problems (Finlayson, 2010) and was implicit in much of the output of lain Duncan Smith's Centre for Social Justice policy think tank. The Centre's influential report Dying to Belong (CSJ, 2009) which underpinned several strands of Cameron Conservative public policy - on gangs and youth violence, on families and social responsibility - famously inverted the widely accepted relationship between cause and consequence when it described a youthful generation being lost 'as they plunged through violence and criminality to hopelessness and despair' (CSJ, 2009: 9). Britain's gang culture was said to be the product of such environments, often to be found in the country's most deprived and marginalised communities. And just as the causes are laid at the feet of feckless or irresponsible individuals, so, according to Bauman (2008), neoliberal politics encourages individuals to find their own 'individual solutions to socially generated problems, and to do it individually, using their own skills and individually possessed assets'. In turn, he noted, this tended to put people in competition with one another, making communal solidarity seem 'irrelevant if not downright counter-productive' (Bauman, 2008). ${ }^{1}$

If individuals had to solve their own problems by hard work and a strong dose of social responsibility, it is then but a short step to the idea that 'dysfunctional' or broken families might be 'turned around' by appropriate intervention (Kirby, 2009). This, of course is precisely the aim of the Troubled Families programme (Bond-Taylor, 2014), a punitive form of social welfare (Phoenix, 2009) closely aligned with crime and disorder management, which, as Hancock and Mooney have argued, performs the routine but 'increasingly pervasive' surveillance and intervention 'to regulate and control working class lives and communities' (Hancock and Mooney, 2013). Accordingly, under the Conservative-led Coalition Government of 2010-15, welfare reform became increasingly characterised by conditionality and benefit sanctions, measures which eventually meshed with the Troubled Families programme and a corresponding array of anti-social behaviour measures thereby establishing a wide-ranging regime of compliance management interventions, the 'soft end' of the spectrum of social controls described by Bell (Bell, 2015).

Welfare, Conditionality and Sanctions

When, in Punishing the Poor (2009), Loic Wacquant described similar regime changes, from 'welfare' to 'workfare', in the USA, he outlined a process whereby the benevolent 'left-hand' of the state withdrew, and the more punitive 'right hand' extended, replacing social supports with social controls. In the UK, by contrast, perhaps especially in England and Wales, it is difficult to describe so abrupt a transformation, notwithstanding the austerity driven expenditure cuts underpinning the 'Welfare Reform' agenda. For although significant aspects of the welfare reform programme appear primarily intended to demonstrate a lowering of the cost of the benefit system to the notional 'taxpayer', it remains the case that substantial sums are still being invested in social support, although the purpose of this support is no longer to meet 'liveability' needs, but rather to incentivise, cajole

\footnotetext{
${ }^{1}$ The contrast here between neo-liberalism's individualist perspective and that advocated by C. Wright Mills in The Sociological Imagination (1959) can hardly be more profound. In 1959 Mills had argued that the essential role of the social scientist was to 'translate private troubles into public issues'. Neo-liberalism's fragmentary vision, by contrast, seeks to turn social problems into personal responsibilities - or, in some cases, no-one's responsibility, just personal misfortunes.
} 
and coerce people into employment. Universal Credit, lain Duncan Smith's comprehensive new welfare support system and the Work Programme, which replaced the former 'jobseekers allowance', became compulsory for all unemployed benefit claimants over 25 who had been out of work for a year (9 months for those aged 18-24). Claimants are referred to government selected service providers, the majority being private companies, tasked with helping the unemployed back into work. Formal agreements (we turn to consider these 'quasi-contracts' later in our discussion) or 'claimant commitments' are drawn up outlining the support and services offered to the unemployed and the obligations of claimants spelled out. The service providers, like the agencies involved in the Troubled Families programme, are paid according to the results they achieve, sustained job placements. Evaluation of the programme by the National Audit office in 2014 revealed that over 2 million claimants were expected to have been referred to the programme by March 2016, at a cost of $£ 2.8$ billion (NAO: 2014). Roughly one in four of those referred were finding employment (although only $11 \%$ of those deemed 'harder to help'), but the target threshold implied only moving "into employment lasting six months or longer" (NAO, 2014: 4). Six months hardly constitutes secure and stable employment, especially for the lower-skilled sectors in which a majority of placements were being achieved. Savings of $£ 41$ million were reported by the NAO compared with "similar levels of performance on previous welfare-to-work programmes", but a loss of $£ 11$ million was reported (anticipated to rise to $f 25$ million) relating to payments made to contractors for nonvalidated employment placements (that is, payments for employment placements not achieved). Concluding its 2014 Review, the NAO noted overall:

It is not yet clear that the Work Programme has substantially improved on past performance or met its other aims for helping people into work. In particular the Department has struggled to improve outcomes for harder-to-help groups. Contrary to the intentions of the Work Programme, contractors are spending less on people in these groups and there are signs that some people receive very little support. The Work Programme is also not working as the Department intended in the way it rewards contractors for performance. Flaws in contracts and performance measures have led to unnecessary and avoidable costs (NAO, Summary 2014: 8).

The reference to the outcomes for 'harder to help' groups is tellingly complemented by a discussion of the 'parking' of these 'difficult' groups - effectively, the warehousing of the unemployable. Similar issues have been identified in earlier 'welfare-to-work' programmes, and in other reports on the Work Programme (Work and Pensions Select Committee, 2013) but alongside the Programme's lack of effective support for needy people and perverse incentives for contractors to claim payments for services not delivered, the evidence clearly suggests a policy intended to discipline and disentitle those excluded from the labour market rather than meet their needs.

Similar issues arise in respect of the 'benefit sanction' processes, the complementary compliance control systems intended to 'responsibilise' claimants and reduce the length of time that people spend in receipt of welfare benefits. Beatty et al. (2015) have reviewed the toughened regime of benefit sanctions installed after 2012 by the Welfare Reform Act of that year. They note that not only were the length and severity of benefit sanctions increased, but there has also been a significant step change in the frequency with which they are applied, for example the number of JSA sanctions applied almost tripled from a rate of 2.5 per 100 claims to 7.1 per 100 in 2014 . The monthly average number of Jobseekers Allowance (JSA) sanctions rose from 35,500 a month prior to October 2012 to a monthly average of 84,800 after this date. Likewise there was a three-fold increase in Employment Support Allowance (ESA) sanctions from 1,400 per month in March 2013 to 5,400 in March 2014. While the key rationale for the sanction system concerned the need to change claimant behaviour in order to reduce unemployment, Beatty et al., suggested there is 'no robust evidence to support this claim' (Beatty et al., 2015) leading to questions being asked regarding both the fairness and effectiveness of the benefit sanctions. Overall, Beatty et al., concluded that rather 
than benefit sanctions fostering a culture change amongst claimant groups they in fact often have counter-productive effects, piling additional hardships upon the already most vulnerable, further excluding those facing the greatest barriers to mainstream employment opportunities.

During the first few months of 2015 Frances Ryan produced a series of compelling reports in the Guardian newspaper detailing sixty suicides under investigation by the DWP where it was thought that a benefit sanction decision had been the immediate trigger to the claimant killing him or herself (Ryan, 2015a). A month later, following an Inquest suicide verdict on another claimant, a Jobcentre advisor described the 'constant and aggressive' pressure she was placed under by management to meet performance targets 'almost by persecuting people' (Ryan, 2015b; O'Hara, 2015). Later in the year, the aggressive culture of benefit conditionality and sanctioning were exposed by a battery of Fol requests revealing that over 80 people a month were dying after being declared 'fit for work'. In total, 2,380 people died between December 2011 and February 2014, shortly after being declared fit for work and rejected for sickness and disability benefits or Employment Support Allowance. A further 7,200 claimants died after being awarded ESA and having been placed in the work related activity category in order to be prepared for a return to work (Ryan, 2015c).

Such evidence of the pressure placed upon claimants reflects the broad conclusions reached by Griggs and Evans who acknowledged that there was a substantial 'gulf between the rhetoric and the evidence for the effects of sanctions in welfare reform. The gulf is not just on evidence, but also in different approaches to preventing poverty and promoting opportunity' (Griggs and Evans, 2010). UK Governments have committed themselves both to evidence-based policy making and eliminating child poverty by supporting 'hard-working families' (although often invoking the unfortunate language of 'strivers and skivers' when doing so). Yet, as Griggs and Evans conclude, there is still rather limited evaluation of the real consequences of benefit sanctions in practice, 'policy-makers continue to justify extending sanction-backed conditionality on moral grounds while taking an ambivalent attitude to the evidence' (Griggs and Evans, 2010: 7). The available qualitative evidence tends to suggest that, while sanctions might induce labour market compliance, they have relatively little effect upon underlying motivations to work (Ibid.).

A substantial body of international econometric evidence, some of which is reviewed by Griggs and Evans (2010), points to benefit sanctions having some impact upon a narrow range of labour market behaviours, such as reducing the duration of periods of unemployment and raising employment participation rates. Such initiatives, however, are usually only evaluated in the short term and often allow few conclusions about the quality, durability or sustainability of the work placements achieved. Many such largely econometric evaluations also fail to take account of a range of social factors such as the institutionalisation and recycling of poorer quality employment opportunities (unstable jobs and lower pay), the reproduction of long term family poverty, poorer outcomes for children, poorer health and damaging consequences for especially disadvantaged groups; few studies go on to explore the wider crimogenic consequences of benefit sanctions.

Arriving at such troubling conclusions about the Work Programme, welfare conditionality and benefit sanctions, the 'soft controls' and compliance measures of austerity, brings us back to the core paradox of 'broken society' 'common-sense'. It will be recalled that the central concerns of the 'broken society' argument, first articulated in the original Centre for Social Justice Breakdown Britain report of 2006 included family breakdown, educational failure, worklessness and economic dependence, addictions and indebtedness (CSJ, 2006). The underlying similarities between these socalled 'pathways into poverty' (rather than consequences of poverty) and Charles Murray's underclass thesis from a decade and a half earlier are striking. More to the point, with family poverty, the institutionalisation of long term social disadvantage and poorer outcomes for children shown to be a direct consequence of greater welfare conditionality and benefit sanctions, it 
becomes difficult to avoid the conclusion that the Government's tough 'broken society' compliance measures reproduce the very broken society (fragmenting relationships, fractured communities, social exclusions and especially marginalised and demonised youth) that they claim to be addressing. They appear to be the measures least likely to produce the 'stable two-parent family life' seen by the government as vital in mending Broken Britain and thereby reducing levels of long term poverty.

The related case of indebtedness, a parallel world of compliance, individualisation and responsibilisation, is also instructive. For aside from the social and opportunity costs associated with the Conservative-led Coalition's high profile decision to increase student loans and abolish educational maintenance allowances, the longer term picture reveals 'a steady and problematic increase in personal debt in the UK' over the last two decades (Ben-Galim \& Lanning, 2010). Almost two thirds of people on annual incomes below $£ 10,000$ exhibit 'problematic levels of indebtedness' (Walker et al., 2015). Furthermore, debt is especially problematic for families in relative poverty. Research for the CAB has shown that debt clients were typically poor, 'with a high proportion of people in receipt of means tested benefits' (Edwards, 2003). Walker has noted that 'for a growing number of people, personal debt supplements their existence in a relatively low wage and insecure employment landscape' (Walker, 2011: 526). Despite this, the largely unregulated pay-day loan and 'personal debt industry' exercises its own disciplinary compliance, confirming, often physically reinforcing, a sense of individual responsibility for poverty and perceived financial mismanagement. And, just as the compliance processes within systems of benefit sanctioning serve mainly to institutionalise inequality and social exclusion so, likewise, it is hardly in the interests of the debt industry to either abolish debt or to allow debtors to escape (Walker et al., 2015).

As Levitas has argued (2012: 12), reviewing the impact of a range of government policies, the cumulative impact has been rising unemployment and increasingly precarious temporary and lowwaged employment, reductions and restrictions in benefits and, in particular, an assault on the living standards of families with children'. This is the contrived policy context in which families encounter 'difficulties' and 'troubles'. Furthermore, the Institute for Fiscal Studies (IFS) predicted in 2012 that, as a consequence of recent government policies, the numbers of children living in households in absolute poverty would grow and those in relative poverty would increase after 2013 (Joyce, 2012). Yet despite this broader policy context, as Bond-Taylor has noted, 'concerns about criminality and ASB' rather than poverty and disadvantage came increasingly to shape the emerging governmental agenda (2014: 143).

This is certainly not the first time that problems of poverty, inequality and disadvantage have been refracted through the moralising language of 'desert', culpability and irresponsible lifestyle choices, on the contrary there is a long history of this stretching back into the early 19th century and beyond. And as Golding and Middleton astutely noted, over thirty years ago, the British have long exemplified a difficulty in distinguishing poverty from crime (Golding and Middleton, 1982). Both the Prime Minister and his Chancellor of the Exchequer have appeared prone to the same errors. In 2013, following the prosecution of a man who had killed six of his own children in an incompetent attempted arson compensation case, George Osborne claimed that Mick Philpott 'embodied everything that was wrong with the welfare state' and questioned the purpose of 'subsidising lifestyles like that' (Dolan and Bentley, 2013). A few years earlier, David Cameron had been equally scathing of 'welfare lifestyles' following the sentencing of two people for a contrived 'kidnap' scam. Cameron argued, his comments drawn straight from the Breakthrough Britain phrasebook, that the case was a:

'damning verdict of our broken society... a family held together by drink, drugs and deception... An estate where decency fights a losing battle against degradation and despair. ...Children suffer[ing] at the very sharpest end of our broken society ... all over the country are other young victims, too. Children whose toys are dad's discarded drink bottles; whose role models are criminals, liars and 
layabouts; whose innocence is lost before their first milk tooth. What chance for these children? Raised without manners, morals or a decent education, they're caught up in the same destructive chain as their parents. It's a chain that links unemployment, family breakdown, debt, drugs and crime. (David Cameron, 2008b, quoted in Mooney, 2010)

This criminalised conception of the disadvantaged - especially poor families and their marginalised young people - is the necessary precursor to the new systems of (anti-social) contractual governance embodied in our contemporary measures for 'Troubled Families' interventions, youth employment and training, and the youth justice and anti-social behaviour management practices to which we now turn.

\section{Anti-social contracts ?}

We propose to discuss the various areas of policy mentioned above within a single frame, that of anti-social contracts. The case for doing so should become clear as the argument develops. In the first place, each of the four policy areas impinges directly or indirectly upon the problematic question of marginalised youth. As Ferguson convincingly demonstrates, since the 1970 s each recession has had an increasingly worse impact upon young people, while each recovery benefitted them less; likewise policies have directly discriminated against them with $16-24$ year olds excluded from the 'national living wage' and the denial of automatic housing benefit to those aged 18-21 (Ferguson, 2016). In the second place, as Guy Standing has noted, 'youth make up the core of the precariat' (Standing, 2011: 66). He describes three such 'precarity traps', although he rather overlooks a fourth. His first precarity trap relates to disadvantaged, broken and dysfunctional family backgrounds; the second involves the loss of positive masculine role models, including ambition, access to networks or what used to be called the 'work ethic'; and the third, partly a consequence of the last, concerns the drift into peripheral non-economic (or illegitimate economic) roles including addiction, apathy and gangs where alternative kinds of role model might be found. Standing describes gang membership, disaffection and petty criminality as 'part of the wider precarity trap for young men' (Standing, 2011). Hallsworth and Lea have referred to this as a kind of 'selfwarehousing', (2011: 22), the internalisation of a sense of failure and responsibility, the most abject forms of which are reflected in the escalating suicide and para-suicide rates amongst young, economically marginal, males (Ellison, 2014). The final precarity trap rather overlooked by Standing concerns criminalisation itself and the impact of criminal convictions and periods of imprisonment upon subsequent career opportunities and future employability.

This infamous NEET generation, caught in a fractured transition between family dependence and full labour market involvement and economic independence, is increasingly engaged by attitudinal, behavioural and especially criminal justice, interventions preoccupied by risks, riots and radicalisation. Increasingly surveillance and control, and governance through crime and disorder management are presented as logical and rational responses to the problems of marginalised youth. In each of the areas addressed, the governance of youth goes beyond the compliance management described already and instead takes on a profoundly anti-social and frequently counter-productive contractual form where behaviour is closely regulated, responsibility is fixed in a rigid onedimensional fashion and significant consequences follow breaches of the contract.

Contractual principles run throughout the Troubled Families and Anti-Social behaviour interventions, most conspicuously so in the varieties of Acceptable Behaviour Contract designed to nip 'offensive and disorderly' behaviour of younger children in the bud, but which do so by potentially jeopardising the social housing tenancies of the families involved (Stephen \& Squires, 2004). Similarly, contractual aspects form part of the system of police 'final warnings' in that young people have to agree the offence of which they are accused and also consent to undertake such activities as form part of the final warning programme. Essentially similar arrangements underpin the Referral Order, 
first introduced in 2002, and available to Youth Courts in the case of offenders aged 10-17 who are in court charged with an offence for the first time. As the Ministry of Justice Referral Order (RO) guidance stipulates, the young offender must admit the offence with which they are charged and then 'under the order the young offender agrees a contract with the [referral] panel which can include reparation or restitution to their victim, for example, repairing any damage caused or making financial recompense, as well as undertaking a programme of interventions and activities to address their offending behaviour' (Ministry of Justice, 2015).

As we have noted earlier, (Squires and Stephen, 2005: 100-102), the contractual elements of these orders, forms part of a wider strategy of 'responsibilisation governance' derived from a conception of the contractual balance between rights and duties which is frequently invoked in contemporary public policy, especially crime and disorder management. Yet while some commentators have criticised ROs for the way in which they attempt to graft an artificial notion of restorative justice onto what is actually an enforcement process (Haines, 2000), our main concern about this order has concerned the doubtful kind of contract upon which it is based. While presented as consensual, the $\mathrm{RO}$ is actually based upon compulsion (an order made by the Youth Court) and a major imbalance of power between young people and an alliance of enforcement interests (youth justice workers, community representatives, referral panel members, the police and victims); for instance, from the outset, young people were not allowed any legal representation when before the panels to discuss the contents of their 'contracts' (Wonnacott, 1999). As was argued when the ROs were first introduced, such arrangements could give rise to de facto 'institutionalised bullying' (Wedd, 2000), while other commentators questioned the compatibility of the RO procedures with existing international principles of youth justice (Goldson, 2000). And in our own research, despite receiving assurances about how 'contracts' and agreements were very carefully compiled in full discussion with young people themselves, we continued to find examples of young people who either couldn't remember the compliance requirements of their own contracts, or didn't actually understand what they meant (Squires and Stephen, 2005). There might also be something ethically doubtful about requiring a young person aged 10-12 to commit to a contract, they would not be considered legitimate in many other areas of social life.

Contractual principles, the balancing of duties and responsibilities, are implicit in many of the 'twostep injunction' processes (Simester \& Von Hirsch, 2006) which, following the Anti-Social Behaviour, Crime and Policing Act 2014, characterise the powers intended to regulate a wide array of criminal and 'pre-criminal' behaviours. For example, drawing upon the former ASBO 'on conviction', generally referred to as the CrASBO, the new (post 2014) criminal behaviour order, imposed following conviction for a criminal offence might include any number of prohibitive conditions (avoiding any associating with certain people, staying away from certain places or activities and maybe keeping curfew hours), or treatment conditions, such as attending designated drug and alcohol treatment services. As Simester has argued, such orders entail a principle of 'two-step criminalisation', a first step attaches the conditions to a specifically targeted subset of persons, the second step applies enhanced or up-tariff penalties (Simester \& Von Hirsch 2006). Similar considerations apply to the Gang Injunctions sometimes referred to as Gang-bos introduced in 2011. They are targeted at young people at risk of being drawn into gang activity but the focus is upon preventing violence, attached conditions can involve behaviour change requirements and mentoring but also certain prohibitions (people, places). Gang injunctions can be awarded according to the lower, 'civil law' burden of proof, the balance of probabilities, and hearsay evidence can be heard in support of an application.

The public space protection order extends the 'first step' principle even wider and can impose behavioural conditions on anyone using the designated area. No prior convictions are required and the behaviour which is regulated comprises that which is 'unreasonable' rather than illegal although 
'likely to have, a detrimental effect on the quality of life of others in the locality' (Home Office, 2014). This suggests that the PSPO falls squarely into the sphere of 'pre-criminal regulation', reiterating the sense of 'institutional mistrust' experienced by marginalised young men over recent years (Brown, 1998; Kelly, 2003). Breach of a PSPO is a criminal offence which can be punishable by a $f 100$ fixed penalty notice or a fine. Amongst a number of critics, Liberty have argued that the PSPO is too vaguely drawn and open-ended while the grounds for appeal are especially narrow. Furthermore, the penalties for breach can be issued by either the police or by certain designated local authority officials (Liberty, 2015). There seems every indication that the 'usual suspects', especially marginalised young men, will continue to be at the focus of the new legislation, just as they were in respect of preceding ASB powers (Bottoms, 2006; Bannister and Kearns, 2012).

In sum, a pervasive sense of distrust, sustained in part by de-civilising and criminalising discourses of youth (France, 2007) have perpetuated a sense that youth itself, or at least that visible, urban, segment of it, is somehow deemed 'anti-social' by nature and that extraordinary measures, what Ferguson, drawing upon Habermas, refers to as 'juridification processes' - 'when actions or behaviours become subjects of statute law as part of a wider trend towards extending the reach of the law into the domains of the lifeworld' (Ferguson, 2016: 195) - are considered necessary. These extraordinary measures, which become even more markedly unjust and anti-social when the young people in question are deemed to be members of a gang - for which some of the most oppressive police powers and punitive forms of racist surveillance and 'dragnet justice' are reserved (Bridges, 2013; Williams and Clarke, 2016) - are themselves divisive, unfair and profoundly anti-social. Squires originally floated a concept of 'anti-social policy' in 1990, it was centred upon the apparent consequences of 'the privatisation of the economy, the domestication of social care and the centralisation of political authority... the retrenchment of civil liberties while advanc[ing] the power of private property, defending the privileges of rank and reasserting the merits of inequality, patriarchy and nationalism' (Squires, 1990: 2).

In particular, the argument continued, 'policies which have widened inequalities and exacerbated social tensions, restricted rights to welfare, increased the numbers suffering poverty or homelessness, or undermined the aspirations of many whilst leading even more people to suspect that their overall quality of life is declining, might well merit the label 'anti-social' (Ibid., 2). Rolling forwards nearly three decades and it appears that for many young people the essential contract relationship at the heart of social citizenship, of belonging, has been shattered. This suggests a broken contract rather than a 'broken society'2. Young people are variously described as 'disaffected', 'disconnected', 'excluded', 'non-participating' or 'marginalised' although the language is often ambiguous, inconsistent or simply wrong. Sometimes it is a question of what young people are connected to, rather than simple 'disconnection' - for instance, it should be recalled that the Centre for Social Justice Report was titled Dying to Belong (CSJ, 2009). The primary concern involved what they did belong to - supposedly gangs - rather than their complete isolation. And, in place of the wider social contract, expressed in an idea of citizenship, young people, as we have seen, are increasingly confronted by a formidable array of disciplinary - behaviour, compliance and performance - contracts, some specifically tailored to the needs of individuals, others more generic in nature, some designed for designated groups, but all deploying sanctions, penalties and exclusions as a consequence of breach or non-performance. But of all the anti-social and quasi-contracts gaining comment and attention in recent years, few have attracted more attention than zero-hours contracts.

\footnotetext{
2 This may not be the only broken 'contract' discussed in similar terms, for, following evidence of the numbers of former military personnel, either in prison, suffering PTSD or related psychological conditions, or homeless, a number of commentators have voiced concerns about the 'Armed Forces Covenant' (Gillan and NortonTaylor, 2007). The Ministry of Defence re-issued the covenant in 2011.
} 
To begin with, however, it is important to acknowledge that, zero-hours contracts are certainly not confined exclusively to young people, but that said, young people certainly feature significantly amongst the most insecure, temporary and poorly paid sections of the labour market. ${ }^{3}$ A survey commissioned by the trade union Unite suggested that, across the country, 5.5 million people were subject to zero-hours contracts, most of them young people. Thirty-six per cent of those on the contracts said they were not entitled to holiday pay and over three quarters received no sick pay (Butler, 2014). While supporters emphasise the flexibility such contracts offer to employers with fluctuating work patterns (such as seasonal work) and even facilitating choices for some employees about when and how much to work, Len McCluskey, General Secretary of Unite, described zero hours contracts as 'a growing scandal... creating a sub-class of insecure and low-paid employment' (cited in Butler, 2014). While the benefits of labour market flexibility, traded off against job security and workforce sustainability makes a certain kind of narrow, econometric, business sense, facilitating the effective management of risk, reducing the costs of recruitment and training, and even, for some less scrupulous employers, as a means of avoiding particular employment obligations, the day to day operation of zero-hours contracts, tells a different story. This involves a picture of employees living permanently as if 'on-call', reluctant to turn down work for fear it may not be offered again (being 'zeroed down'), while attempting to juggle the flexible incomes from flexible working with the largely inflexible demands of housing costs, running a home, caring for children and synchronising access to tax credits and other income benefits (Pennycook et al, 2013; Adams and Deakin, 2014).

Yet while there is plenty of econometric research on zero hours contracts, there appears relatively little empirical sociological research into the anti-social and exclusionary consequences of shifting employees onto zero-hours contracts. Notwithstanding this, employment commentators have drawn attention to the break, signified by zero-hours contracts, with an inclusive Keynesian social contract which, as Levitas has argued, understood social inclusion as a form of social citizenship, an aspect of labour market participation (Levitas, 1996). By contrast, according to Elliott (2013) zero hours contracts re-establish a precarious 'reserve army' of low-waged, low skilled and low opportunity, temporary, labour. As Elliott notes, these are precisely the kinds of conditions that the union movement as a whole sought to overcome. In place of an idea of working associated with respect and aspiration (Sennett, 2004), a standard of living and the dignity of labour, notions barely grasped by barren contemporary management discourses on the 'work-life balance', zero hours contracts establish anti-social, coercive and exploitative, performance and compliance systems that detract from a sense of belonging, reinforce social divisions and exclusions, and which resemble, in all relevant respects, the wider regime of anti-social contracts impinging upon the lives of the youngest and poorest. This is especially the case with evidence emerging that, in an effort to put further pressure on jobseekers and fill notified vacancies, Job Centre staff were able to 'sanction' benefit claimants (under the new universal credit system) if they did not apply for and show willingness to accept certain zero-hours jobs (Mason, 2014), despite concerns that such work could disrupt training and apprenticeship opportunities, tying young workers into permanent insecure and low paid employment. As we have indicated, it is not so much 'society' which is broken, but rather the bond between important sections of the population and the state. And at this point we turn to the final aspect of our argument.

\section{Conclusion: The failing state?}

\footnotetext{
${ }^{3}$ An early legal discussion of zero hours contracts, from 2002, concluded 'there is no doubt that the casual/zero hours worker personifies precarious work and that many such workers are amongst the worst treated in the labour market' (Leighton, 2002: 77), and adding, 'such one-sided working relationships are unusual in other EU states... there is often some incredulity on the part of lawyers... that such a working relationship can be legally valid' (ibid., 72).
} 
Any discussion of 'state failure' will inevitably beg important questions, rooted in political theory and philosophy, about the various roles and purposes of states; what they seek to achieve, and the discourses of rights and well-being with which they surround themselves. So how might we argue that 21st century neo-liberalism is failing the poorest, neglecting a marginalised generation of working class youth, rolling back their expectations and aspirations of social mobility and equal opportunity and condemning them to a lifetime of precarious, dissatisfying, low-waged employment with only impoverished social provision in the event of unemployment, ill-health and eventual retirement: from cut-price cradle to early grave.

Another means by which to assess state performance might be to draw upon a more comparative approach, judging the performance of states against a group of similar nations, 'European partners', OECD nations, or something similar. Of course, in the wake of BREXIT, it may well be said that Britain has declared itself rather less interested in such comparisons. Even so, the exceptional work of Wilkinson and Picket, in The Spirit Level (2010) provides a compelling portrait of the relations between inequality and a range of social problems (from mental disorders, crimes, infant mortality rates and poor health), but it is the comparative regime analysis developed by Pantazis and Pemberton (2009) which gives us a direct purchase on the question of state performance. Pantazis and Pemberton's work feeds directly into the discussion of anti-social policies and failing states, for their concern is with differing kinds of state and policy regime and the production of social harms. Like Wacquant (2009), they recognise that socio-economic outcomes such as mass incarceration, widening patterns of inequality and the increasingly marginal status of many young, working class, men, is not an inevitable outcome of inexorable social and economic forces but the result of clear political decisions. Their article then proceeds to itemise the greater or lesser harms associated with social democratic, corporatist and neo-liberal state regimes. They then proceed to match these regime types to a range of policy outcomes data from the WHO, UNICEF, ILO and the OECD, relating to a series of social, material and psychological needs such as: basic physical health, infant and neonatal mortality, life expectancy, education and literacy, economic activity, 'personal autonomy', housing, material and environmental deprivation, social and political participation, as well as security, 'autonomy' and 'recognition' (Pantazis and Pemberton, 2009).

The conclusions they draw from this international survey centre upon the consistently poor performance of the neo-liberal regime type, which, they say, appears to assume that 'the benefits accrued through economic growth outweigh the inequalities that are inherent in this form of [state] organisation' (2009: 231). They note that while some 'may benefit from the freeing of the market, a series of collateral harms result which far outweigh those occurring in other regimes.' The UK, in particular, they note, is also 'marked by high levels of economic insecurity, reflected in the persistence and extent of relative poverty and inequality' (2009: 232). In a similar vein, the UNICEF child welfare 'Report Card' for 2013 placed the UK 16th (out of 29) 'affluent countries', but significantly below virtually all other western European societies, on a series of 5 measures of wellbeing: material well-being, health and safety, education, behaviours and risk, and housing and environment, with the UK ranking especially lowly on educational opportunity, behaviours and risks and health and safety.

Translating these figures into the very specific example of violence victimisation, Danny Dorling, supported by Bellis et al's (2011) research on Accident and Emergency hospital admissions, has made a strong empirical case that inequality and deprivation are powerful drivers of violent victimisation (Dorling, 2005). Marginalised young men living in 'deprived areas' are over three times more likely to access A\&E services following a violent assault. ${ }^{4}$ Drilling even further into these

\footnotetext{
${ }^{4}$ Furthermore, following the introduction of A\&E police reporting protocols involving gang-related and weapon violence, there are strong grounds for thinking that gang-involved young people are especially
} 
disproportionate violence figures, ONS data for the period 2011-2013 shows that, even as overall homicide rates have fallen, young black men are four and a half times more likely to be victims of homicide than young whites (ONS, 2014). As Dorling has concluded, murder rates, are increasingly concentrated in the poorest areas. Murder (and interpersonal violence) has become significantly concentrated in the poorest and most deprived parts of Britain (Shaw, Tunstall and Dorling, 2005). And as Dorling emphatically concludes 'murders are at the tip of the pyramid of social harm and their changing numbers and distributions provide one of the key clues as to where harm is most and least distributed' (Dorling, 2005: 40). In effect, even this least 'ideological' and most 'intimately' individual of crimes, undoubtedly the most terminal of criminal harms, can be seen to reveal the profound influence of social forces, and political choices. In turn these choices are shaped by priorities, reflecting contrasting political ideologies, which have allowed the growth of inequality, tolerated the existence of poverty, whilst driving the social exclusion and disentitlement to which the marginalised young and least qualified have been subject.

At the same time, as Dorling has noted, there appears something in the British outlook that accepts, as natural, the pattern of social inequalities and the harmful injuries of class associated with it. Even as the rift between the richest and the poorest began to stretch still wider following the political changes of the 1980s, overhauling the principles of collectivism and universalism that had sustained key features of what was once the 'welfare state', so an even more virulent and vituperative series of attitudes towards the poor and marginal has taken hold, deriding the poor for their 'failure' and condemning the young as violent, 'chavs' and 'scum' (Tyler, 2008; 2013; Hayward and Yar, 2006; Pickard, 2014). The irony that the principal victims of the 'broken society' are blamed for its condition represent just one further aspect of this British paradox.

Yet violent victimisation is only part of our story. The 'broken society' analysis with which we began this discussion is not just a question which concerns the simple distribution of harms and victimisation, it has also concerned, as David Cameron, quoted earlier, demonstrated, the organisation of a power to stigmatise, criminalise, ostracise and punish. This is the power to produce a criminality against which society's moral and juridical forces might be deployed, to demonstrate once and for all the feckless and irresponsible condition of the poor and their need for discipline, supported by compliance processes, sanctions and punishment. To take our commentary full circle we have chosen to conclude by referring briefly to the excellent IPPR study, Make me a Criminal (Margo and Stevens, 2008). Drawing upon cross-European evidence of diminished social provisions and falling quality of life indicators for young people, the authors demonstrate conclusively the precarious and overwhelmingly crimogenic contexts in which marginalised young people in the UK are forced to live. Cumulatively, the withdrawal of social supports, the rates of educational exclusion and underachievement, the disrupted family backgrounds, the collapse of the youth and young adult labour markets and the transition and training opportunities that went with them, and, not least, the hostile ideological climate they face in many areas of life have detached and disaffected a generation. In turn, the strategies they adopt - street socialisation, nuisance behaviours, substance misuse, peer group activities and gang formation - 'delinquent solutions' all over again (Downes, 1966) - are further demonised, regulated and criminalised. In sum, the anti-social governance of contemporary marginalised youth invariably produces and reproduces the very problems it bemoans; this is not a broken society, more a failure of government.

reluctant to visit $A \& E$ where the injuries they have sustained are not thought to be serious or life-threatening, see Squires (2011). 


\section{References}

Adams, Z. and Deakin, S., 2014. Re-Regulating Zero Hours Contracts. Institute of Employment Rights, London.

Bannister J. and Kearns A. 2012 Overcoming intolerance to young people's conduct. Criminology and Criminal Justice 13(4): 380-397.

Bauman, Z. 2008 The Absence of Society, www.jrf.org.uk/publications/absence-society.

Beatty, C., Foden, M., McCarthy, L. and Reeve, K., 2015 Benefit Sanctions and Homelessness: A Scoping Report. Sheffield Hallam: Centre for Regional Economic and Social Research.

Bell, E. 2015 Soft Power and Freedom under the Coalition, Palgrave Macmiilan.

Bellis, M.A., Hughes, K., Wood, S., Wyke, S and Perkins, C. 2011, National five-year examination of inequalities and trends in emergency hospital admission for violence across England. Injury Prevention, Vol 17: pp.319-25.

Ben-Galim, D., \& Lanning, T. 2010. Strength against the shocks. Low income families and debt. London: Institute for Public Policy Research.

Bond-Taylor, S. 2014 The Politics of ASB within the 'Troubled Families' Programme, in S. Pickard (ed.) Anti-Social Behaviour in Britain: Victorian and Contemporary Perspectives. Palgrave Macmillan.

Bottoms, A.E. 2006 Incivilities, Offence and Social Order in Residential Communities, in A. von Hirsch and A.P. Simester (Ed.) Incivilities: Regulating Offensive Behaviour. Oxford, Hart Publishing.

Bridges, L. 2013 The Case against Joint Enterprise, Race and Class 54(4): 33-42.

Brown, S., 1998. Understanding youth and crime: listening to youth?. Buckingham, Open University Press.

Butler, S. 2013 Zero-hours contracts: 5.5m Britons 'are on deals offering little guaranteed work'. The Observer, 8.9.2013.

Cameron, D. 2008a, 'Fixing our broken society', The Conservative Party, www.conservatives.com.

Cameron, D. 2008b 'There are Five Million People in Britain on Benefits: How do we stop them turning into Karen Matthews', Daily Mail, December 8.

Centre for Social Justice, 2009 Dying to Belong: An In-Depth Review of Street Gangs in Britain, London, CSJ.

Dolan, A. and Bentley P. 2013 Vile Product of Welfare UK. Daily Mail April $3^{\text {rd }}$.

Dorling, D. 2005 Prime suspect: murder in Britain in Hillyard, P., Pantazis, C., Tombs, S., Gordon, D. and Dorling, D. (2005) Criminal Obsessions: why harm matters more than crime. London: Pluto Press.

Downes, D., 1966 The Delinquent Solution: A Study in Subcultural Theory. Routledge. 
Driver, S. 2009 “Fixing our broken society': David Cameron's post-Thatcherite social policy', in S. Lee and M. Beech, The Conservatives under David Cameron: built to last? Palgrave, Basingstoke.

Edwards, S. 2003. In too deep: CAB clients' experience of debt. Citizens Advice. Retrieved from https://www.citizensadvice.org.uk/in-too-deep.pdf

Elliott, L. 2013 Zero-hours contract workers - the new reserve army of labour? The Guardian, 4.8.2013,

Ferguson, R. 2016 Young People, Welfare and Crime: Governing non-participation. Bristol, the Policy Press.

Finlayson, A., 2010. The broken society versus the social recession. Soundings, 44(1), pp.22-34. France, A. 2007 Understanding Youth in Late Modernity, Buckingham, Open University Press.

Gillan, A. and Norton-Taylor, R. 2007 Care of soldiers compromised by failing Army pact. The Guardian, 15.08.07.

Golding, P. and Middleton, S. 1982 Images of Welfare: Press and Public Attitudes to Welfare. Oxford, Martin Robertson.

Gregg, P., 1994. Out for the count: a social scientist's analysis of unemployment statistics in the UK. Journal of the Royal Statistical Society. Series A (Statistics in Society), Vol. 157(2): 253-270.

Griggs, J. and Evans, M. 2010 Sanctions within Conditional Benefit Systems: A Review of Evidence. Joseph Rowntree Foundation, www.jrf.org.uk.

Haines, K. 2000 Referral Orders and Youth Offender Panels, in B. Goldson (ed.) The New Youth Justice. Lyme Regis Russell House Publishing.

Hallsworth, S. and Lea, J. 2011 Reconstructing Leviathan: Emerging Contours of the Security State, Theoretical Criminology Vol. 15(2): 141-157.

Hancock, L. and Mooney, G., 2013. "Welfare ghettos" and the "broken society": Territorial stigmatization in the contemporary UK. Housing, Theory and Society, 30(1), pp.46-64.

Hayward, K., \& Yar, M. (2006). The 'chav' phenomenon: Consumption, media and the construction of a new underclass. Crime, Media, Culture, 2(1), 9-28.

House of Commons Work and Pensions Select Committee, 2013 Can the Work Programme Work for all User Groups? First Report of Session 2013-14. HC 162, London, The Stationery Office.

Joyce, R. 2012 Tax and benefit reforms due in 2012-13, and the outlook for household incomes, IFS Briefing Note BN126, London: Institute for Fiscal Studies.

Kelly, P., 2003. Growing up as risky business? Risks, surveillance and the institutionalized mistrust of youth. Journal of youth studies, 6(2), pp.165-180.

Kirby, J., 2009. From broken families to the broken society. The Political Quarterly, 80(2): 243-247. 
Leighton, P., 2002. Problems Continue for Zero-Hours Workers. Industrial Law Journal, 31(1), pp.7178.

Levitas, R., 1996. The concept of social exclusion and the new Durkheimian hegemony. Critical social policy, 16(46): 5-20.

Levitas, R. 2012 There may be 'trouble' ahead: what we know about those 120,000 'troubled' families. ESRC Policy Response Series, No. 3.

Liberty (2015) Campaigning against: Public Space Protection Orders, available at: www.libertyhuman-rights.org.uk/campaigning/public-space-protection-orders-0

Margo, J. and Stevens, A., 2008. Make me a Criminal. Preventing Youth Crime. London: Institute for Public Policy Research.

Mason, R. 2014 Jobseekers being forced into zero-hours roles The Guardian 5.5.2014.

MacDonald, R., (ed.) 1997. Youth, the 'underclass' and Social Exclusion, Routledge.

Mills, C.W. 1959 The Sociological Imagination. New York, Oxford University Press.

Ministry of Justice, 2015 Referral Order Guidance, London, MoJ.

Mooney, G. 2009. The 'broken society' election: class hatred and the politics of poverty and place in Glasgow East. Social Policy and Society, 8(4) : 437-450.

Mooney, G., 2010. The disadvantaged working class as' problem' population: The 'Broken Society' and class misrecognition'. Concept: The Journal of Contemporary Community Education Practice Theory, 1(3).

Morris, L. and Irwin, S., 1992. Employment histories and the concept of the underclass. Sociology, 26(3), pp.401-420.

Murray, C.A. 1990. The emerging British underclass. London: IEA Health and Welfare Unit.

NAO (National Audit Office) 2014 The Work Programme: Department of Work and Pensions: Report by the Comptroller and Auditor General. HC 266, Session 2014-15.

ONS (Office for National Statistics) 2014, Homicide Statistics. London, The Stationery Office

O'Hara, M. 2015 As a Jobcentre advisor I got 'brownie points' for cruelty, The Guardian 4.2.2015.

Pantazis, C., Gordon, D. and Levitas, R. 2006, Poverty and Social Exclusion in Britain, Bristol, The Policy Press

Pantazis, C. and Pemberton, S., 2009. Nation States and the Production of Social Harm: Resisting the Hegemony of 'TINA'. In R. Coleman, and D. Whyte (ed.), State power crime, Sage, pp.214-233.

Pennycook, M., Cory, G. and Alakeson, V. 2013 A Matter of Time: The rise of zero-hours contracts. The Resolution Foundation. 
Pickard, S., 2014. The Trouble with Young People These Days: 'Deviant' Youth, the Popular Press and Politics in Contemporary Britain. Labelling the deviant: othering and exclusion in Britain from past to present. French Journal of British Studies, 19(1): 91-121.

Phoenix, J 2009 "Beyond Risk Assessment: The Return of Repressive Welfarism." In McNeil, R. \& Barry, M. (Eds.) Youth Offending and Youth Justice: Research Highlights in Social Work. Jessica Kingsley, London.

Ryan, F. 2015a Suicides hi-light the grim toll of benefit sanctions in austerity Britain. The Guardian, 3.1.2015

Ryan, F. 2015b How many benefits claimants have to kill themselves before something is done? The Guardian, 10.2.2015

Ryan, F. 2015c Death has become part of Britain's benefit system The Guardian, 27.8.2015

Sennett, R. 2004 Respect: The formation of character in an age of Inequality. London, Penguin books.

Shaw, M., Tunstall, H. and Dorling, D., 2005. Increasing inequalities in risk of murder in Britain: trends in the demographic and spatial distribution of murder, 1981-2000. Health \& place, 11(1), pp.45-54.

Simester A.P. and von Hirsch, A. 2006 Regulating offensive conduct through two-step prohibitions, in A. von Hirsch and A.P. Simester (Ed.) Incivilities: Regulating Offensive Behaviour. Oxford, Hart Publishing.

Smith, D.J., 1992. Defining the underclass. in Smith (ed.) Understanding the Underclass, PSI, London, UK.

Standing, G. 2011 The Precariat: The new dangerous class. London, Bloomsbury Academic.

Squires, P. 1990 Anti-Social Policy: Welfare, Ideology and the Disciplinary State, Hemel Hempstead, Harvester/Wheatsheaf Books.

Squires, P. 2011 Young People and Weaponisation, in Goldson (ed.) Youth in Crisis: 'Gangs', territoriality and violence, Routledge.

Squires, P. and Stephen, D.E. 2005 Rougher Justice: Anti-Social Behaviour and Young People. Willan Publishing.

Stephen, D.E. and Squires, P. 2004 Community Safety, Enforcement and Acceptable Behaviour Contracts: An Evaluation of the work of the Community Safety Team in the East Brighton 'New Deal for Communities' Area. University of Brighton, HSPRC Report

Tyler, I. 2008 "Chav mum chav scum" Class disgust in contemporary Britain." Feminist media studies Vol. 8 , no. $1: 17-34$

UNICEF 2013 The Well-being of children: How does the UK score? Unicef Score sheet 11: https://www.unicef.org.uk/Images/Campaigns/ReportCard11_CYP.pdf 
Wacquant, L. 2009 Punishing the Poor: The Neo-liberal Government of Social Insecurity. Duke University Press.

Walker, C., 2011. "Responsibilizing" a Healthy Britain: Personal Debt, Employment, and Welfare. International Journal of Health Services, 41(3): 525-538.

Walker, C., 2012. Personal debt, cognitive delinquency and techniques of governmentality: Neoliberal constructions of financial inadequacy in the UK. Journal of Community \& Applied Social Psychology, 22(6): 533-538.

Walker, C., Hanna, P., Cunningham, L. and Ambrose, P., 2015. Parasitic encounters in debt: The UK mainstream credit industry. Theory \& Psychology, Vol. 25 (2): 239-256.

Wilkinson, R. and Picket, K. 2010 The Spirit Level; Why Equality is better for Everyone. London, Penguin Books.

Williams, P. and Clarke, B. 2016 Dangerous Associations: Joint Enterprise, Gangs and Racism, London, Centre for Crime and Justice Studies.

Wilson, J.Q. and Kelling, G.L., 1982. Broken windows. Atlantic monthly, 249(3): 29-38.

Work and Pensions Select Committee 2013 Can the Work Programme Work for all User groups? First Report of Session 2013-14. House of Commons, HC 162. 